\title{
Non-Member psychiatrists
}

It was agreed at a recent meeting of Council that psychiatrists who are not registered members of the College and not likely to take its Membership Examination should have the opportunity to participate in the College's educational activities.

Non-member psychiatrists can apply to the College to be included on a mailing list which will enable them to:

(a) receive programmes for Quarterly Meetings

(b) receive programmes for Divisional Meetings

(c) receive programmes for Specialist Section Meetings (up to a maximum of two Sections).
This facility will cost $£ 40$ and will be renewable on 1 July each year. Non-member psychiatrists can also subscribe to the British Journal of Psychiatry (current UK subscription rate $£ 78$ ) and the Psychiatric Bulletin (£10.00).

Members of the College are asked to draw this notice to the attention of non-member psychiatrists who can apply to the Secretary for further details.

VANESSA CAMERON The Secretary

\section{Morris Markowe Public Education Prize}

The Public Education Prize will be awarded annually for an article on a psychiatric topic of approximately 1000 words, suitable for publication in a regional newspaper, lay journal, the paramedical press or a general practitioner's magazine. At the time of submission, the article(s) submitted must not have been published previously.

Entries will be judged for topicality and newsworthiness by designated members of the College's Public Education Committee, and a prize of $£ 200$ will be awarded for the successful entry.
The prize may only be awarded to Members or Inceptors of the College below the rank of consultant psychiatrist or equivalent at the time the entry is submitted.

Entries for the prize should be submitted to Professor B. Pitt, Public Education Officer, at the College, by 1 May of each year.

Further details of this prize will be included in the Prize Leaflet to be sent out with the Winter Quarterly Meeting 1990 programme this Autumn.

\section{Attendance at Quarterly Meetings}

Council has agreed that, in future, all Members must register if they wish to attend Quarterly Meetings. Although it has previously been College policy to enable Members to attend the Scientific Sessions without registering, the costs of hiring lecture theatres, audio-visuals and printing are now so high that Council has decided that Members attending should pay a greater contribution. Although the meetings will continue to be subsidised, the daily registration fee will be increased from the Annual General Meeting 1989.

April 1989 